\title{
Aeolian transportation of sand and dust in the Aral Sea region
}

\author{
G. Issanova $\cdot$ J. Abuduwaili $\cdot$ O. Galayeva $\cdot$ \\ O. Semenov $\cdot$ T. Bazarbayeva
}

Received: 20 March 2014/Revised: 11 December 2014/Accepted: 4 January 2015/Published online: 20 January 2015

(C) Islamic Azad University (IAU) 2015

\begin{abstract}
The aeolian transport of dust, sand and salt is a common process in southern Kazakhstan, as well as in the Aral Sea region. Anthropogenic desertification and the desiccation of the Aral Sea have occurred in the basin since 1960. The whole area of the desiccated seafloor is now a new salt desert, and it became an active source of dust, sand or salt storms. The newly formed Aralkum desert was found to be the dominant source of aeolian sand, dust and salt aerosols. Additionally, the most frequent storms were observed in Pre-Aral Karakum and Kyzylkum deserts, where these storms occurred from 40 to 110 days average per year. Aeolian sands and dusts flowed mainly from eastern and north-eastern to the western and south-western directions. The highest amount of sand transportation was observed at the Aral Sea meteorological station. The lowest amount was at the Kazaly meteorological station. Furthermore, transported sand mass has increased at this station during last decade. Most meteorological stations found
\end{abstract}

G. Issanova $(\bowtie) \cdot$ J. Abuduwaili

State Key Laboratory of Desert and Oasis Ecology, Xinjiang Institute of Ecology and Geography, Chinese Academy of

Sciences, 818 South Beijing Road, Ürümqi 830011, Xinjiang, China

e-mail: agamprit@gmail.com

G. Issanova

U.U. Uspanov Kazakh Research Institute of Soil Science and Agrochemistry, Almaty 050060, Kazakhstan

G. Issanova - T. Bazarbayeva

Department of Energoecology, Faculty of Geography and Environmental Sciences, Al-Farabi Kazakh National University, Almaty 050040, Kazakhstan

O. Galayeva · O. Semenov

Kazakh Research Institute of Ecology and Climate,

Almaty 050022, Kazakhstan three maximums of sand and dust transportation, namely in 1966-1970, 1984-1986, and 2000-2002, that is, three periods, like a cycle about every 15 years. Overall, most of the meteorological stations showed the slight decrease in sand and dust transportation that may be explained by fixing sand control measures and other activities which have been done against deflation processes in the region.

Keywords Aeolian process - Sand transport . Aral Sea region - Aralkum desert

\section{Introduction}

Aeolian processes, manifested by dust and sand storms, are natural events that occur in arid and semi-arid regions worldwide. Almost all major sources of dust/sand storms are located over topographical lows or on lands adjacent to strong topographical highs, where fluvial action is evident by the presence of ephemeral rivers and streams, alluvial fans, playas and saline lakes (Prospero et al. 2002; Issanova et al. 2013). During dust and sand storms, sand-, silt- and clay-sized particles can be removed by winds from the surface and transport over great distances (Al-Dousari and Al-Awadhi 2012; Issanova et al. 2013). Significant quantities of mud particles may be blown thousands of kilometres from their source (Semenov 2011; Groll et al. 2012). Dust storms are characterized by strong winds that transport of huge amounts of dust particles (Semenov 2012; Gills 1996; Micklin 2007). Sandstorms differ from dust storms on the basis of height of transfer and particle size, and are often combined with dust storms in areas where sand prevails (Yang et al. 2002). Sand particles 0.1 and $1 \mathrm{~mm}$ in diameter are transported close to the surface (the distance over which they are transported per day rarely 
reaches $1 \mathrm{~km}$ ), normally forming sand dunes that can creep up to 10 or $50 \mathrm{~m}$ per day (Semenov 2011). Dust particles are much smaller and more easily transported and often to rather high parts of the atmosphere, thus capable of reaching distances hundreds of kilometres away from the origin. They are accompanied by more intensive transfer of soil and strong turbidity of the atmosphere (Semenov 2011; Uteshev and Semenov 1967).

Dust storms are the main cause of air pollution in Central Asia, including Kazakhstan, affecting the ecology as a whole, and the health and living conditions at local levels (Micklin 2007; Chub 1998; Abdirov et al. 1993; Tursunov 1989).

Dust, sand and salt storms occurring in Central Asian, Kazakhstan natural and anthropogenic deserts transport large amounts of deflated material over long distances, significantly affecting agricultural areas as well as human health (Chub 1998; Gills 1996; Micklin 2007). Aeolian dust can also increase the soil salinity (Popov 1998) and reduce the photosynthetic efficiency (Usmanov 1998; Razakov and Kosnazarov 1996). Agricultural lands mainly suffer from intensification of soil salinization, increase in the salinity of surface and ground water, degradation of pastoral vegetation and ultimately lead to decrease in agricultural crops (Kuz'mina and Treshkin 2009; Shardakova and Usmanova 2006). Large-scale anthropogenic changes such as the drying of the Aral Sea led to the formation of new salt and dust-emitting sites, which has become the new source of dust and salt storm outbreaks (Breckle et al. 2001; Orlovsky et al. 2004; Opp 2007; Micklin 2007).

During the first half of the twentieth century in the Aral Sea basin, the demand for usable water increased due to an expansion of the irrigated area $(+40.6 \%$ between 1918 and 1960), the rise of cotton as the dominant crop $(+189.7 \%$ between 1918 and 1960) and intense population growth $(+128.7 \%$ between 1918 and 1960) (Dukhovny and de Schutter 2011). As a result of this development, Aral Sea inflow drastically decreased, leading to a loss of almost $90 \%$ of the volume and $74.3 \%$ of the surface area of the lake (Micklin 2007; Dukhovny 2008). The once fourth largest inland lake in the world desiccated into three fragments, of which only the northern part (the "small Aral") was considered salvageable. The southern part of the Aral Sea is now a desert called the Aralkum (Opp 2007), covering more than $57,500 \mathrm{~km}^{2}$ (August 2011) (Indoitu et al. 2012; Groll et al. 2012) (Fig. 1). The impact of the Aralkum as the dominant source of aeolian salt, sand and dust is limited to a region of approximately $500,000 \mathrm{~km}^{2}$ surrounding the former
Aral Sea (Groll et al. 2012). The salt, sand and dust storms are particularly endangering the productivity of agricultural areas and ecosystems by enhancing salinization. Since the mid-1970s, satellite images have revealed major salt/dust plumes extending as far as $500 \mathrm{~km}$ downwind that drop dust and salt over a considerable area adjacent to the sea in Uzbekistan and Kazakhstan, and to a lesser degree Turkmenistan (Micklin 1991, 2004; Glazovskiy 1990; Ptichnikov 2002). Although dust/salt storms affect the entire zone surrounding the Aral, most of the major storms occur in north and north-east winds, which most seriously impact the Usturt Plateau to the sea's west and the Amudarya delta at the south end of the water body (Bortnik and Chistyaevaya 1990). The salt and dust also have ill effects on wild and domestic animals by directly harming and reducing their food supply (Palvaniyazov 1989). These are prominent problems in the Aralkum region. This newly formed desert is different from other deserts in the region-not only because of its anthropogenic origin, but also because of its chemical composition. The Aral Sea topsoil contains 8-10\% salt, mostly sulphates and chlorides (Orlovsky and Orlovsky 2001). The total mass of salts contained in the Aral Sea is estimated to be about $6 \times 10^{9}$ metric tons, which would result in a salt layer of at least $0.5 \mathrm{~m}$ thickness covering the entire Aralkum (Létolle et al. 2005). The store of the latter in the aeration zone of the ground is 2,200 tons ha ${ }^{-1}$ (Orlovsky and Orlovsky 2001). For many decades, the Aral Sea has been a sink for the particulate and dissolved matter transported by the Amudarya and Syrdarya rivers. This matter included geogenic mineral loads as well as unprocessed wastewater with high concentrations of heavy metals, especially lead and cadmium (Wiggs et al. 2003), radioactive substances (uranium and radon) from the ore processing industry in the upstream countries of Tajikistan and Kyrgyzstan (Kulmatov and Hojamberdiev 2010), urban and industrial wastewater discharges from an increase in inhabitants from more than $14 \times 10^{6}$ in 1960 to almost $50 \times 10^{6}$ in 2011 (Dukhovny and de Schutter 2011) and highly concentrated, leached agrochemicals, pesticides and salts used to combat widespread salinization (Micklin 1988, 2007; O'Hara et al. 2000; Whish-Wilson 2002).

The accumulated pollutants of the Aralkum are subject to aeolian transport. A reported variation from 40 and $150 \times 10^{6}$ tons year $^{-1}$ of salt and dust blows out of the exposed bottom of the sea (Micklin 1988, 2010). By other estimations, the total amount of deflated material from the Aralkum is up to $15-75 \times 10^{6}$ tons annually, which raises considerable concerns in terms of the impact on human 
Fig. 1 Changing the Aral Sea profile and formation of Aralkum desert (1960-2009) water covered area-dark grey, dry sea bottom-light grey (modified after Groll et al. 2012)
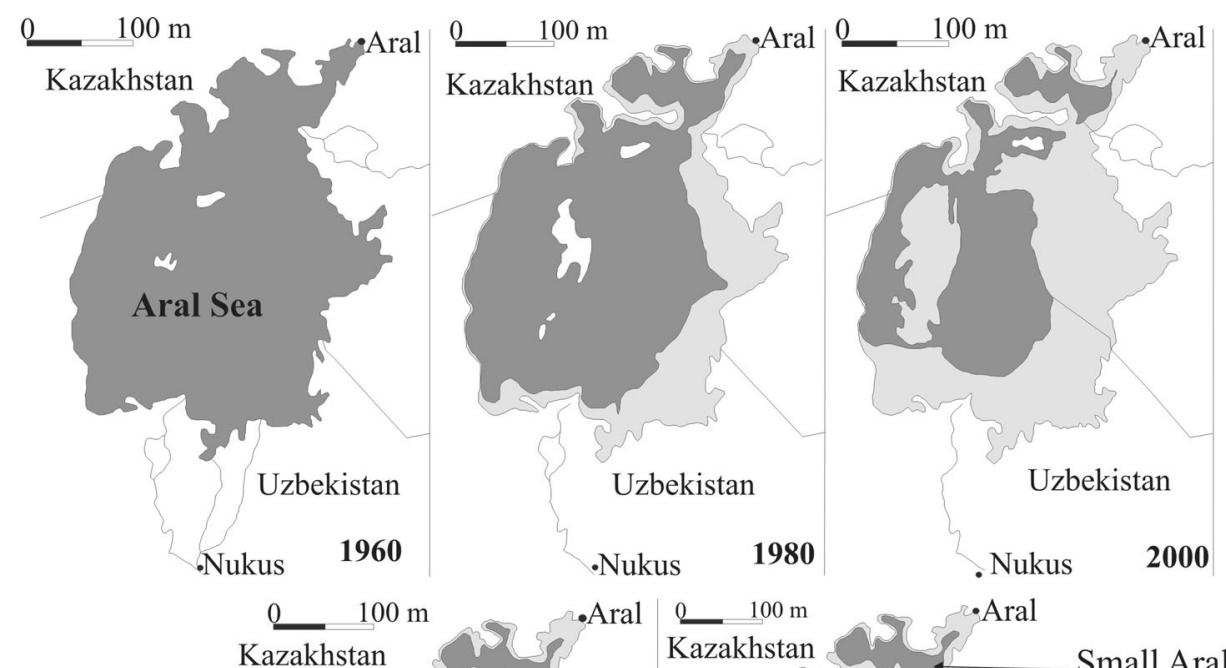

Kazakhstan
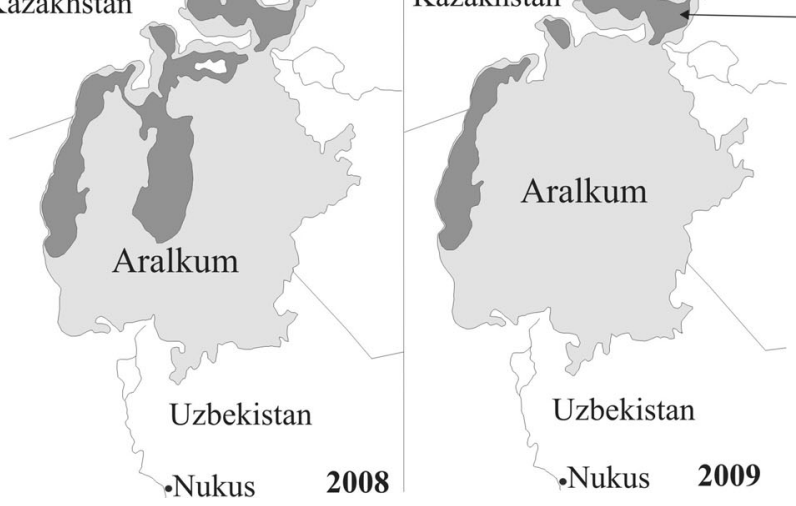

Small Aral Sea health (Saiko and Zonn 2000) since the annual global mass of dust aerosols is between 100 and $200 \times 10^{6}$ tons (Shi and Zhao 2003; Groll et al. 2012). In spite of importance of aeolian processes monitoring, many regularities of the sand and dust transportation are poor understood.

The main purposes of this paper were to conduct a quantitative assessment of sand and dust transportation during deflation and thus determine the mobile sand process in the Aral Sea region.

Study area

Aeolian sand and dust transportation is a natural process. Its intensity and impact can be amplified in regions where anthropogenic components are added. This is the case in the Aral Sea basin, located mostly in the Central Asian countries of Kazakhstan and Uzbekistan. The basin is characterized by natural sandy deserts like the Pre-Aral Karakum, Kyzylkum and Karakum, and the Usturt Plateau (Fig. 2). Annual precipitation is $<100 \mathrm{~mm}$ in the central lowlands near the Aral Sea and in the Kyzylkum and Karakum deserts (Indoitu et al. 2012; Opp 2005). Unlike many other arid areas, the Aral Sea basin is also intensely cultivated.

The climatic conditions of the Aral Sea region are mainly governed by relatively low elevation (Budyko 1974). Based on a variety of synoptic processes, rainfall patterns, annual and inter-annual temperatures, the $\mathrm{Ka}$ zakhstan part of the Aral Sea belongs to the northern climatic province, characterized by cold and dry continental patterns of a Central Asian climate. Mean annual temperature is between 5 and $11{ }^{\circ} \mathrm{C}$. Total rainfall varies between 80 and $200 \mathrm{~mm}$ (Rachkovskaya 2003). Chemical composition of the soil is sulphate-chloride (Orlovsky and Orlovsky 2001), formed on the sandy and loam maritime soils.

Most parts of the Aral Sea region are predominantly covered by fine sands and soils, highly prone to wind erosion and the formation of aeolian landforms (Semenov 2009). Grain sizes average from 90 to $160 \mu \mathrm{m}$ on the desiccated seafloor and are smaller in young territories (desiccation in 1980, 1990, 2000) and larger in old (1960, 1970). Adjacent desert areas (former coastal dunes, former islands and sandy deserts) have an average particle size of 
Fig. 2 Study area. Sand and dust transportation in the Aral Sea region

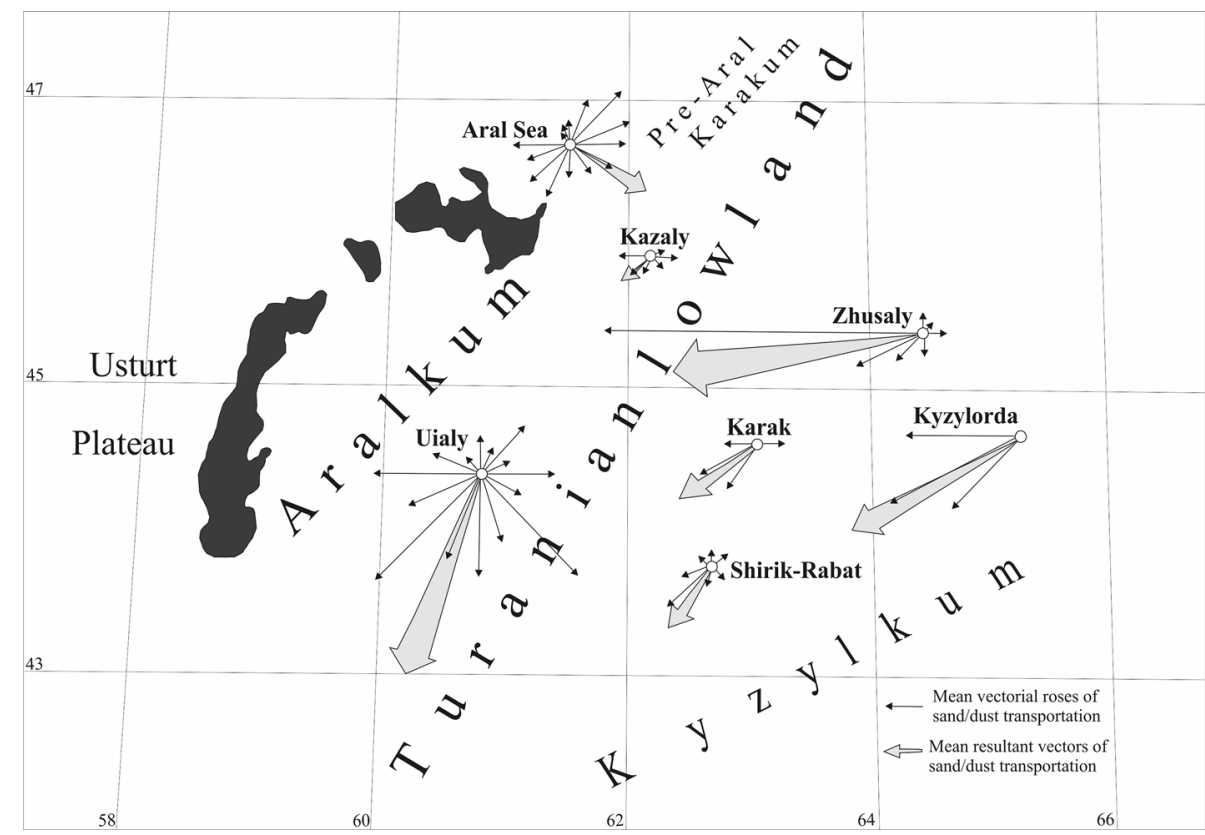

170-270 $\mu \mathrm{m}$, which make them highly susceptible to wind transportation, especially across long distances (Semenov 2009, 2011).

\section{Materials and methods}

Dust and sand storms transport a huge amount of dust/sand particles. For calculation of amount of sand transported by the wind in the ground layer during sand deflation, the physical-statistical model of the sand storm was used (Semenov 1988, 2009). This allows to calculate the amount of dust which is transported through a distinct migration plain of $1 \mathrm{~km}$ in length by sand drift (between 10 and $30 \mathrm{~m}$ ) and by dust transport (between 150 and $200 \mathrm{~m}$ ) (Semenov 2012). The material transported between 0 and $10 \mathrm{~m}$ is often rather course sand moving by saltation, the material transported between 30 and $150 \mathrm{~m}$ is course dust and salty particles, and above $200 \mathrm{~m}$ small dust particles prevail, which are often transported over very long distances (Semenov 2011, 2012). The model was used for a detailed assessment of the intensity of deflation and transportation of the dust aerosol beyond the dried bottom of the Aral Sea. As input data for models use standard observations of dust storms at meteorological stations: wind speed and average geometrical size of sand particles in the investigated area. It is based on the masts measurements of wind speeds, sand and salt mass transported during storms in the $10 \mathrm{~m}$ high layer. This is the level of installation of the wind measuring devices at meteorological stations. In our investigation, for the purpose of analysis and calculation of sand and dust transportation in the Aral Sea region as input data models, the wind speed, direction and average sand particles sizes from seven meteorological stations (Aral Sea, Kyzylorda, Zhusaly, Kazaly, Karak, Shirik-Rabat and Uialy) from 1966 to 2005 were used to conduct the assessment and determine dominant direction of sand movement during the deflation processes. The following analytical expression approximates the profiles of solid sand discharge measured during expeditions:

$q(z)=q_{1}\left(\frac{z}{z_{1}}\right)^{-0.57 \frac{w_{g}}{u_{*}}}$

where $q(z)$ is the sand discharge at height $z$ in $\mathrm{kg} /\left(\mathrm{m}^{2} \mathrm{c}\right)$; $q_{1}$ is the same at height $z_{1} ; w_{g}$ is the free deposition speed of sand particles of average size (hydrodynamic bigness of particles); $u_{*}$ is the friction speed; and $w_{g}-1.6-2.0 \mathrm{~m} \mathrm{~s}^{-1}$, $u_{*}-0.2-0.3 \mathrm{~m} \mathrm{~s}^{-1}$.

Dependence of the total sand discharge

$Q_{z}=\int_{0}^{h} q(z) \mathrm{d} z$

On the Froude constant, analogue turned out to be stochastic according to expeditions. Model applies as $50 \%$ 
cumulative probability dependence and should use the equation for the climate studies in sand transportation (Semenov 2011).

$\bar{Q}_{z}=Q_{z 50 \%}=2 \cdot 10^{-7}\left[\frac{u_{*}^{2}}{\left(g \cdot x_{o}\right)}\right]^{2}$

where $g=9.8 \mathrm{~m} \mathrm{~s}^{-2}$ is the acceleration of gravity and the average geometrical size of sand particles on the active surface which is $x_{0}=170-270 \mu \mathrm{m}$.

Due to the discrete measurement of wind speed at the stations, the amount of sand $(M)$ transported during a storm in $\tau$ duration should be defined not through the integration of total sand discharge continuous function in time, but is to be calculated for discrete intervals of time. Duration of a long storm $\tau$ can be presented as of the sum of intervals

$\tau=\Delta \tau_{0}+n \Delta t+\Delta \tau_{k}$

where $n$ is the number of full standard observations at a meteorological station during a sand storm, $\Delta t$ is the time interval between the standard meteorological observations equal to $3 \mathrm{~h}$ or $10,800 \mathrm{~s}, \Delta \tau_{0}$ is the time interval from the moment of storm beginning to the first next hour of observation and $\Delta \tau_{k}$ is the time interval between last standard hour when the storm was still observed and its termination. Then, the amount of sand transported during the storm can be calculated with the formula

$M=\Delta \tau_{0} \cdot Q_{z l}+\sum_{i=1}^{n} Q_{z i} \cdot \Delta t+\Delta \tau_{k} \cdot Q_{z n}$

where $\Delta \tau_{0}$ is the time interval from the moment the storm began to the next and first hour of observation, $Q_{z i}$ is the total amount of sand in a surface layer of the atmosphere in the $i$ th hour of measurements, $Q_{z l}$ is the total amount at an initial interval of time, and $Q_{z n}$ at the final interval of time. $Q_{z l}$ and $Q_{z n}$ are calculated by wind speeds in the first and last standard measurements during a storm. $\Delta t$ is the time interval between the standard meteorological observations equal to $3 \mathrm{~h}$ or $10,800 \mathrm{~s}, \Delta \tau_{k}$ is the time interval between the last standard hour when the storm was still observed and its termination. In such a manner, sand amounts were calculated for all dust storms and ground sand transportation in the observations archive and two information files are formed. Sand amounts in the first file were considered to be scalar without taking into account a direction of transport. The second file contained vector characteristics of a wind and sand stream, i.e. the amount of sand together with transport direction.

Dry deposition (falling) of sand at various distances from a former initial coast of the Aral Sea was determined by the dependence
$\left(M-M_{\varphi}\right)=\left(M_{0}-M_{\varphi}\right) \exp \left(-\frac{x}{35}\right)$

where $M$ is the dry aerosol deposition on the surface at the distance $x$ from the source of sand escaping, tons $\mathrm{km}^{-1}$ year $^{-1} ; M_{0}$ is the dry aerosol deposition at the border of the source of sand escaping; $M_{\varphi}$ is the background dry deposition; and $x$ is the distance from the source in $\mathrm{km}$. $M_{\varphi}$ was calculated with the radiobalance model of convection formation:

$M_{\varphi}=0.72 \cdot 10^{-3} \exp \left(B / B_{\mathrm{m}}\right)$

where $B=0.36 \mathrm{~mJ} \mathrm{~m}^{-2}$ is the minimal value of a positive hour's sum, reached at 8 a.m.; the minimal value is $1.46 \mathrm{~mJ} \mathrm{~m}^{-2}$ in the afternoon. $B_{n}=0.35 \mathrm{~mJ} \mathrm{~m}^{-2}$ is the minimal value of an hour's sum of net radiation such that the process of convective raisings of the dust in the atmosphere began.

The received model allowed the calculation of sand and dust transported by the wind in various Kazakhstan regions and an estimation of intensity of sand deflation. Additionally, it also built the vectorial roses of the sand transportation in the region. The vectorial roses display which masses of dust and sand were transported in the lower atmosphere by wind and in which direction. The length of the vector arrow represents the amount of sand and dust transported (Fig. 2). This is known from changes in the shape of the newly formed barchans and other aeolian relief forms that can change direction several times according to the prevailing strong wind vectors. However, the resultant (vector addition) gives an idea of the overall long-term sand and dust movement and transport integrated over time (Fig. 2). The resultant vector shows the final direction of the sand and dust transport.

\section{Results and discussion}

Average amount of long-term sand and dust transport during storms

Average long-term amount of sand and dust transported in the Aral Sea region during storms was variable. Calculated figures from the Semenov model for means of sand and dust masses transported through a cross-sectional migration plane of $1-\mathrm{km}$ length in the lower atmosphere are shown in Table 1. This information is very important for the quantification of dust storms, which is necessary for decisions in terms of protecting 
Table 1 Statistical characteristics of transported sand and dust masses for some meteorological stations in the Aral Sea region (observation period 1966-2005), $M$-amount of sand and dust tons $\mathrm{km}^{-1}$ year $^{-1} ; \sigma$-mean square deviation tons $\mathrm{km}^{-1}$ year ${ }^{-1} ; C_{\mathrm{v}}$ - variation coefficient (Galayeva and Semenov 2011)

\begin{tabular}{|c|c|c|c|c|c|c|c|c|c|}
\hline \multirow[t]{2}{*}{ Meteorological station } & \multicolumn{3}{|c|}{ Dust storm } & \multicolumn{3}{|c|}{ Sand drift } & \multicolumn{3}{|l|}{ Total } \\
\hline & $M$ & $\sigma$ & $C_{\mathrm{v}}$ & $M$ & $\sigma$ & $C_{\mathrm{v}}$ & $M$ & $\sigma$ & $C_{\mathrm{v}}$ \\
\hline Aral Sea & 6,619 & 2,764 & 0.42 & 1,034 & 1,097 & 1.06 & 7,653 & 3,486 & 0.46 \\
\hline Uialy & 3,256 & 3,630 & 1.00 & 2,708 & 3,645 & 1.35 & 5,961 & 6,313 & 1.06 \\
\hline Kazaly & 129 & 188 & 1.49 & 299 & 409 & 1.41 & 428 & 577 & 1.35 \\
\hline Kyzylorda & 986 & 703 & 0.72 & 959 & 720 & 0.75 & 1,940 & 1,238 & 0.64 \\
\hline Zhusaly & 4,272 & 5,846 & 1.37 & 48 & 84 & 1.75 & 4,344 & 5,880 & 1.35 \\
\hline Shirik-Rabat & 722 & 871 & 1.21 & 2 & 3 & 1.8 & 724 & 873 & 1.21 \\
\hline Karak & 1,009 & 1,257 & 1.25 & 2 & 3 & 1.95 & 1,011 & 1,257 & 1.24 \\
\hline
\end{tabular}

and combating the deflation process. The average longterm amount of sand and dust transported during storms was 7,653 tons $\mathrm{km}^{-1}$ year $^{-1}$ at the Aral Sea MS. Of that amount, $86 \%$ was transported by dust storms and $14 \%$ by sand drift. At the Uialy MS 3,255.6 tons $\mathrm{km}^{-1}$ year ${ }^{-1}$, $55 \%$ was transported by dust storms, and $2,708.2$ tons $\mathrm{km}^{-1}$ year $^{-1}$ by sand drift $45 \%$, respectively. At the Kazaly MS, the average amount of sand and dust was 428 tons $\mathrm{km}^{-1}$ year ${ }^{-1}$, and transportation by sand drift was two times more than by dust storms. Total sand transported reached 1,940 tons $\mathrm{km}^{-1}$ year ${ }^{-1}$ and 959 tons $\mathrm{km}^{-1}$ year $^{-1}$ by sand drift, 986 tons $\mathrm{km}^{-1}$ year $^{-1}$ by dust storms at the Kyzylorda MS. At the Shirik-Rabat MS, transported sand mass was 722 tons $\mathrm{km}^{-1}$ year $^{-1}$ most of occurred during dust storms - a phenomena also mirrored by the Karak MS was 1,009 tons $\mathrm{km}^{-1}$ year $^{-1}$ and Zhusaly MS was 4,272.5 tons $\mathrm{km}^{-1}$ year ${ }^{-1}$. The Uialy, Zhusaly and Aral Sea MS showed the high amounts of transported sand. The highest amounts of sand transport can be found at the Aral Sea MS. The lowest amounts are registered at Kazaly MS (Syrdarya river delta).

The aerosol output for the area from the former coastline is also very variable, but very high. Sources for dust in the Aralkum are mainly between former Barsakelmes and Kokaral islands and between Vozrozhdeniya and the former eastern coastline (Semenov 2012). The desiccation of the eastern basin will increase the salt/dust source area tremendously. It is clear that the arid climate and the structure of the desiccated seafloor with the puffy salt crusts are very favourable for the development of farreaching salt/dust storms. Since the environmental and long-term effects of the salt/dust storms may cause nega- tive effects not only on the health of people but also on ecosystems, photosynthesis, the productivity and growth of plants and animals (Semenov 2012; Micklin 2007, 2010; Chub 1998; Abdirov et al. 1993).

Variability of intensive deflation processes from time to time

The mass of sand and dust transportation was found to be highly variable in relation to the climatic fluctuations and varied considerably from time to time (Fig. 3a, b). According to Fig. 3a, b, the peaks of sand and dust transport were observable during storms. The Aral Sea, ShirikRabat and Zhusaly MS had three maximums (1966-1970, 1984-1986 and 2000-2002, respectively). In general, the amount of sand and dust transportation has increased in the Aral Sea MS since 2000, yet at the Shirik-Rabat and Zhusaly MS, transportation decreased (Fig. 3a). Since 1966, a consistent trend of reduced sand and dust transportation has been observed at the Kazaly and Karak MS (Fig. 3b). Sand storms ceased because of the commissioning Kazaly massif of irrigated land. In addition, the Kazaly MS is an enclosed site, located in the southern edge of town and surrounded by residential areas. At the Uialy MS in 1984, the maximum sand and dust transportation recorded at 57,472 tons $\mathrm{km}^{-1}$ year ${ }^{-1}$ which twice more than at the Aral Sea MS. However, since 1985, the sand and dust transportation has been decreasing (Fig. 3b). This was possibly due to the fact that since 1994, observations were reduced due to poor funding and the data were unreliable exclusive of insufficiency (Galayeva and Semenov 2011; Semenov 2012). At the Kyzylorda MS in 1999, a significant increase in sand and dust transportation 

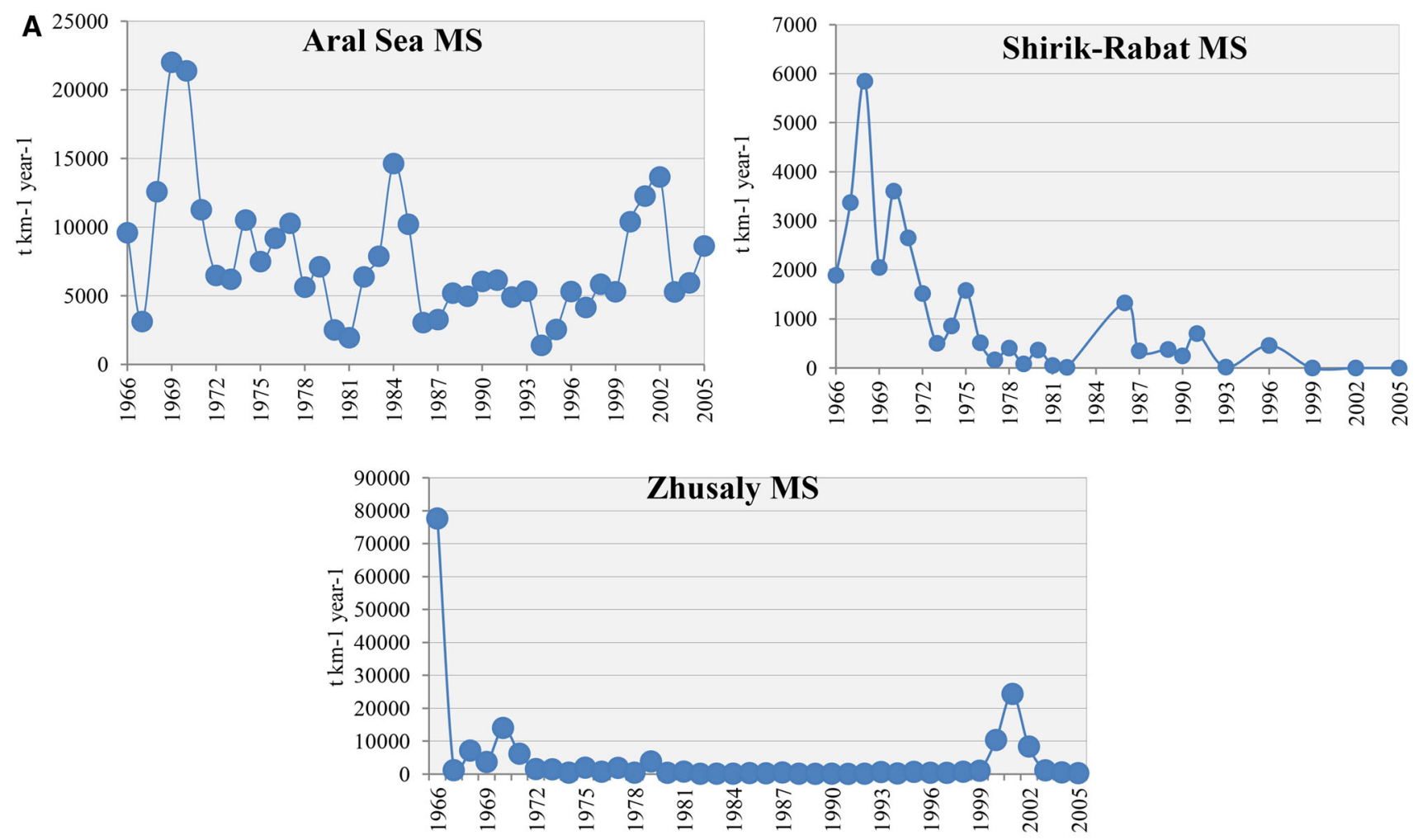

B
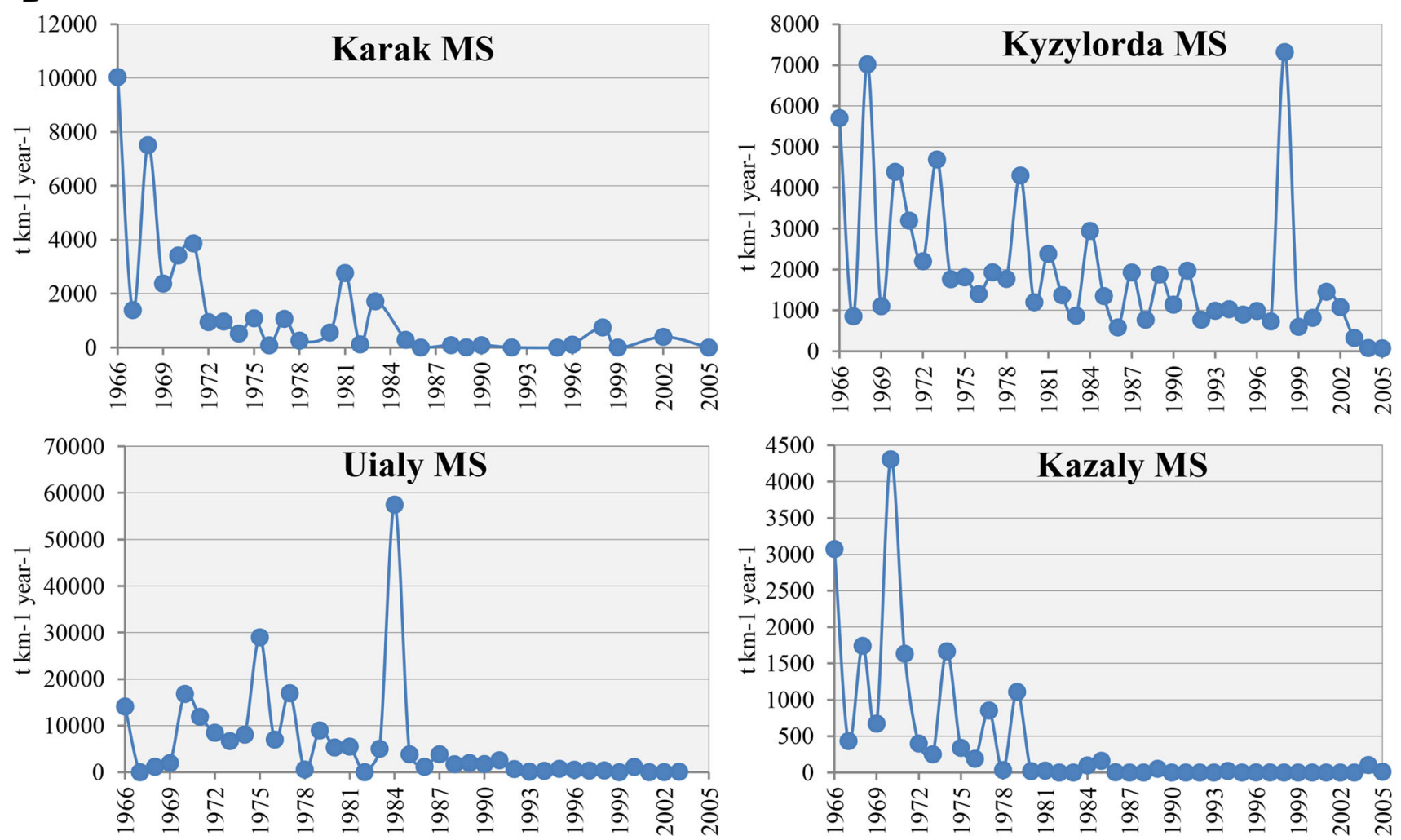

Fig. 3 a, b Dynamics of sand and dust transportation in the east and on the northern coast of the Aral Sea region 
Table 2 Average long-term amount of sand and dust transportation during storms in the Aral Sea region, tons $\mathrm{km}^{-1} \mathrm{year}^{-1}(\mathrm{Galayeva}$ and Semenov 2011)

\begin{tabular}{|c|c|c|c|c|c|c|c|c|c|c|c|c|c|c|c|c|}
\hline \multirow[t]{2}{*}{ Meteorological station } & \multicolumn{16}{|c|}{ Direction $\left({ }^{\circ}\right)$} \\
\hline & 0 & 22.5 & 45 & 67.5 & 90 & 112.5 & 135 & 157.5 & 180 & 202.5 & 225 & 247.5 & 270 & 292.5 & 315 & 337.5 \\
\hline Aral Sea & 78 & 221 & 359 & 344 & 273 & 152 & 115 & 125 & 206 & 235 & 232 & 184 & 199 & 75 & 42 & 51 \\
\hline Kazaly & 3 & 5 & 22 & 30 & 45 & 12 & 7 & 3 & 19 & 40 & 46 & 86 & 86 & 22 & 2 & 1 \\
\hline Zhusaly & 74 & 7 & 116 & 53 & 226 & 38 & 43 & 31 & 154 & 170 & 274 & 428 & 2,684 & 27 & 7 & 13 \\
\hline Karak & 4 & 0 & 12 & 6 & 82 & 44 & 8 & 6 & 26 & 19 & 303 & 359 & 201 & 14 & 7 & 0 \\
\hline Shirik-Rabat & 0 & 18 & 71 & 9 & 30 & 21 & 61 & 7 & 10 & 80 & 377 & 171 & 69 & 7 & 2 & 0 \\
\hline Uialy & 146 & 98 & 283 & 154 & 370 & 276 & 1,143 & 289 & 510 & 382 & 967 & 422 & 529 & 216 & 87 & 89 \\
\hline Kyzylorda & 10 & 10 & 11 & 23 & 31 & 10 & 13 & 9 & 36 & 116 & 446 & 629 & 537 & 49 & 8 & 2 \\
\hline
\end{tabular}

Table 3 Frequency of sand and dust events in the Aral Sea region from 1966 to 1992 (Semenov 2011)

\begin{tabular}{|c|c|c|c|c|c|c|}
\hline \multirow[t]{2}{*}{ Years } & \multicolumn{6}{|c|}{ Meteorological station } \\
\hline & Aral Sea & Uialy & Kazaly & Kyzylorda & Shirik-Rabat & Zhusaly \\
\hline 1966 & 109 & 5 & 55 & 62 & 15 & 30 \\
\hline 1967 & 80 & 1 & 46 & 64 & 19 & 19 \\
\hline 1968 & 86 & 3 & 36 & 70 & 26 & 31 \\
\hline 1969 & 76 & 4 & 25 & 42 & 13 & 19 \\
\hline 1970 & 77 & 35 & 30 & 61 & 19 & 37 \\
\hline 1971 & 58 & 51 & 23 & 40 & 20 & 35 \\
\hline 1972 & 99 & 83 & 10 & 41 & 29 & 13 \\
\hline 1973 & 49 & 48 & 10 & 38 & 6 & 15 \\
\hline 1974 & 59 & 27 & 22 & 60 & 12 & 8 \\
\hline 1975 & 72 & 85 & 17 & 95 & 21 & 13 \\
\hline 1976 & 79 & 39 & 14 & 47 & 9 & 16 \\
\hline 1977 & 79 & 35 & 14 & 64 & 7 & 25 \\
\hline 1978 & 105 & 5 & 3 & 69 & 2 & 13 \\
\hline 1979 & 89 & 21 & 11 & 59 & 1 & 22 \\
\hline 1980 & 59 & 17 & 5 & 55 & 2 & 18 \\
\hline 1981 & 51 & 6 & 1 & 58 & 2 & 9 \\
\hline 1982 & 59 & 1 & 0 & 51 & 1 & 4 \\
\hline 1983 & 101 & 13 & 0 & 48 & 0 & 3 \\
\hline 1984 & 115 & 48 & 4 & 72 & 0 & 6 \\
\hline 1985 & 137 & 6 & 2 & 71 & 0 & 10 \\
\hline 1986 & 85 & 12 & 1 & 69 & 8 & 18 \\
\hline 1987 & 77 & 9 & 0 & 60 & 5 & 13 \\
\hline 1988 & 93 & 10 & 0 & 111 & 0 & 55 \\
\hline 1989 & 85 & 10 & 2 & 122 & 3 & 13 \\
\hline 1990 & 96 & 18 & 0 & 93 & 7 & 9 \\
\hline 1991 & 115 & 14 & 0 & 99 & 13 & 4 \\
\hline 1992 & 69 & 6 & 0 & 110 & 0 & 0 \\
\hline Average (day) & 84 & 23 & 12 & 68 & 50 & 9 \\
\hline
\end{tabular}

was observed at 7,500 tons $\mathrm{km}^{-1}$ year ${ }^{-1}$. In general, the sand and dust transportation in most of the territories (Shirik-Rabat, Karak, Zhusaly, Kazaly and Uialy MS) was slight decreasing that may be explained by fixing sand control measures and other activities, which have been done against deflation processes in the region. 
Sand and dust transport direction in the Aral Sea region

The mean vectorial rose and mean resultant vector of sand and dust transportation are one of the main parameters of the deflation process. According to the result, a vector can find which direction the sand moving by analysing the wind and impact of sand and dust storms in the surrounding territories. The resultant vector also shows the final direction of moving aeolian landforms. The long-term average amount of sand and dust transportation during the storms in the Aral Sea region is shown in Table 2. The differences in sand/dust transportation between northern and southern stations of the eastern Aral Sea region are clearly visible in the table. Maximum sand transportation in the Aral Sea MS was observed heading in east, north-east and south-west directions with 359 and 232 tons $\mathrm{km}^{-1}$ year $^{-1}$, respectively. Minimum sand transportation blew at 42 tons $\mathrm{km}^{-1}$ year $^{-1}$ with north-west direction. At the other MS, which located south of the Aral Sea region, the transportation prevails in west and south-west directions. However, more intensive transport was observed in a south-easterly direction at Uialy MS.

The sand transportation with south-west direction was dominant at the Kazaly, Zhusaly, Kyzylorda, Karak, Shirik-Rabat MS. Karak and Shirik-Rabat MS are located in a region where the anthropogenic influence on the generation of dust is minimal, and there is a little impact of removals from drying areas in the Aral Sea (Galayeva and Semenov 2011). The Kyzylorda MS is analogical by transportation direction with Karak MS, but the amount of sand transportation somewhat more and the maximum sand transportation in the west and south-west direction at 629 tons $\mathrm{km}^{-1}$ year $^{-1}$, western direction that was 537 and 446 tons $\mathrm{km}^{-1}$ year $^{-1}$ to the south-west. On the southernmost Shirik-Rabat MS, the sand transportation is dominant in south-westerly direction with 377 tons $\mathrm{km}^{-1}$ year $^{-1}$, and in rest of directions, the transfer is very small.

A western direction was dominant for Zhusaly MS in the amount of 2,684 tons $\mathrm{km}^{-1}$ year ${ }^{-1}$. Because the fixed sands surround the Kazaly MS, it had the lowest maximum at 86 tons $\mathrm{km}^{-1}$ year $^{-1}$ in west and south-west directions. South-east of 1,143 tons $\mathrm{km}^{-1}$ year $^{-1}$ and south-west of 967 tons $\mathrm{km}^{-1}$ year $^{-1}$ directions were dominant at the
Uialy MS. A large proportion of sand transferred in the south-east direction due to a very intense dust storm on June $15-17,1984$ was 29,000 tons $\mathrm{km}^{-1}$ year $^{-1}$, which is $57 \%$ of the average long-term transportation. In general, in the most central and southern parts of the Aral Sea region, the high amount of transportation was in west and southwest directions; only a few meteorological stations have a maximum amount in the direction of the south-east, east and north-east (Fig. 2). It should be noted that at the Aral Sea MS, the direction of the resultant vector does not coincide with the direction of maximum transfer, since most vectors of north-east and south-west directions. These vectors are completely compensating each other during adding. The long-term resultant vector at following five meteorological stations (Kazaly, Zhusaly, Karak, ShirikRabat and Kyzylorda) in the region has a west-south-west direction. As you can see, these directions are significantly different from the direction of Aral Sea MS. This may be due to specific synoptic processes in the region.

The highest transportation intensity was exhibited at Uialy, Zhusaly and Kyzylorda MS. The highest amount of transported sand was 2,684 tons $\mathrm{km}^{-1}$ year ${ }^{-1}$, observed at Zhusaly MS at $270^{\circ}$ and 1,143 tons $\mathrm{km}^{-1}$ year $^{-1}, 135^{\circ}$ Uialy MS. These new, vast, sandy massifs formed after the sea level dropped, leaving them, exposed and prone to weathering. Consequently, the deflation processes are developed in this region. Thus, the study of the dust and sand transport directions leads to the conclusion that the moving sands process in the north of the 46th parallel occurs in east direction; in the eastern Aral Sea region, the movement of sand which is located in the south of the parallel observed in the west direction with the exception of Uialy MS where the transfer occurs to the south direction.

\section{Frequency of storms}

The high frequency and long duration of dust and sand storms are features of arid regions, including the Aral Sea region. The arid climatic conditions and open surfaces with fine grain sizes are quite favourable for the development of dust and sand storms in the Aralkum area. The amount and size of blown particles depend mainly on the soil surface structure and wind regimes. Strong winds are often recor- 
ded in the region, with mean wind speeds reaching from 6 to $7 \mathrm{~m} \mathrm{~s}^{-1}$ at the meteorological stations of the region. In the summer, the maximum wind speeds can reach 20-25 $\mathrm{m} \mathrm{s}^{-1}$ (Galayeva et al. 1996; Galayeva and Semenov 2011). These natural factors determine the high vulnerability of the territory to the development of deflation processes as a dust and sand storms. The frequency of dust and sand events between 1966 and 1992 at seven Kazakhstan meteorological stations along the Aral Sea region is shown in Table 3.

The Aral Sea and Uialy MS are considered as coastal stations for the period of 1966-1992; continental stations are rest of stations (Zhusaly, Kyzylorda, Kazaly, ShirikRabat and Karak). Active deflation processes were observed at MS in 1966-1968, 1970-1978 and 1983-1991 (Table 3). The most frequent storms were observed in the northern Aral Sea region, where their long-term average frequencies reached 36-84 days year ${ }^{-1}$, compared to 9-23 days year ${ }^{-1}$ in the east (Table 3). The largest dust storm sources were the Pre-Aral Karakum (Aral Sea MS) and Kyzylkum deserts, where dust storms occur from 40 to 110 days out of the year.

The frequency of dust storms in the desert regions of Uzbekistan and Kazakhstan, including most of the Aral Sea region in Kazakhstan, decreased at the end of the twentieth century. Reducing the number of dust storms in the region is due to the large-scale reduction of wind speed on the whole of Central Asia in the late twentieth century (Muminov and Inogamova 1995; Semenov 2011). However, the number of storms has increased at some continental MS: Karakalpalia (Usturt Plateau), Aral Sea and Kyzylorda. This might be an effect of increasing anthropogenic load and not a matter of the regional climatic conditions.

\section{Conclusion}

Human activities have changed the level and volume of the Aral Sea. Syrdarya and Amudarya rivers regulation provoke land/soil degradation and contributed to the development of intensive deflation and desertification processes. The study of the aeolian process in the Aral Sea region allows qualitative assessment of the modern deflation processes intensity in this area. According to the study results, it is possible to do the quantitative assessment of the sands, dust and salt transferred by the wind as well as to develop projects anti-deflation activities and measures.

The dust and sand storms are typical for the Aral Sea and Syrdarya river region with sparse vegetation, climate conditions and soils with light texture. Analysis of the data on dust and sand storms shows that the northern parts of the Aral Sea region exhibited dust storms more frequently than the eastern parts. Nevertheless, in this region, the anthropogenic causes are playing major role in the origin of the dust, sand and salt storms. The Aralkum (man-made desert) and Kyzylkum Deserts became active and main powerful sources for aeolian dust, sand and salt storms and transfer in the Aral Sea basin. The powerful source of aerosols has a great affect on the climate and environmental situation in the Central Asia and Kazakhstan. These aerosols can seriously pollute the air and water lead to the soil salinization and vegetation degradation.

The results of the sand and dust transportation at seven meteorological stations in the Aral Sea region confirmed that aeolian sand and dust occurred mainly in the southwest and southern directions, which also depicted the sand movement process. Sand and dust movement directions of the region allow predicting the possibility of mobile sand process in the Aral Sea region.

\section{Recommendation}

One of the most important strategies is certainly to accelerate the phytomelioration projects in order to form nuclei for spontaneous growth of vegetation cover for combating the salt desertification and sand moving process in the region.

Acknowledgments This study was supported by the National Natural Science Foundation of China (41471098; U1138301).

\section{References}

Abdirov CA, Agadzhanyan NA, Vervikhvost AV, Primbetov KP, Severin AY (1993) Stress reaction of healthy children of Nukus from the effects of ecological factors in Priaral'ye. Vestn Karakalp Otd Akad Nauk Resp Uzb 2:15-20 (in Russian)

Al-Dousari AM, Al-Awadhi J (2012) Dust fallout characteristics within global dust storms major trajectories. Arab J Geosci. doi:10.1007/s1257-012-0644-0

Breckle SW, Wucherer W, Agachanjanz O, Geldyev BV (2001) The Aral Sea crisis region. In: Breckle SW, Veste M, Wucherer W (eds) Sustainable land use in deserts. Springer, Berlin, pp 27-37 
Budyko MI (1974) Change of climate. Hydrometeoizdat, Leningrad Bortnik VN, Chistyaevaya SP (eds) (1990) Hydrometeorology and Hydrochemistry of the Seas of the USSR. vol VIII: Aral Sea. Gidrometeoizdat, Leningrad (in Russian)

Chub VY (1998) Regional problems of estimating the influence of aerosols (of anthropogenic and natural occurrence) on the climatic characteristics of the Central Asiatic region. In: Materials for the regional scientific seminar aeolian transport of salt in the Aral Sea basin, pp 3-4, March 4-5. Tashkent, Uzbekistan: Exec.Comm. Int. Fund Save Aral Sea, World Bank, Main Admin. Hydrometeorol. Uzbekistan (in Russian)

Dukhovny VA (ed) (2008) Comprehensive remote sensing and ground based studies of the dried Aral Sea bed. SIC ICWC, Tashkent, p 173

Dukhovny VA, de Schutter JLG (eds) (2011) Water in Central Asiapast present future. CRC Press/Balkema, Leiden, p 408

Galayeva OS, Semenov OE (2011) Sand transportation by wind in the Aral Sea region. Hydrometeorol Ecol 3:73-85 (in Russian)

Galayeva OS, Semenov OE, Shapov AP (1996) Features of sand transportation in the Aral Sea region. Hydrometeorol Ecol 4:73-93 (in Russian)

Gills TE (1996) Aeolian sediments generated by anthropogenic disturbance of playas: human impacts on the geomorphic system and geomorphic impacts on the human system. Geomorphology 17:207-228

Glazovskiy NF (1990) The Aral Crisis: Causative Factors and Means of Solution. Nauka: Moscow (In Russian)

Groll M, C Opp, Aslanov I (2012) Spatial and temporal distribution of the dust deposition in Central Asia-results from a long term monitoring data. J Aeolian Res. doi:10.1016/j.aeolia.2012.08. 002

Indoitu R, Orlovsky L, Orlovsky N (2012) Dust storms in Central Asia-spatial and temporal variations. J Arid Environ 85:62-70

Issanova G, Jilili A, Semenov O (2013) Deflation processes and their role in desertification of the southern Pre-Balkhash deserts. Arab J Geosci. doi:10.1007/s12517-013-1106-z

Kulmatov R, Hojamberdiev M (2010) Distribution of heavy metals in atmospheric air of the arid zones in Central Asia. Air Qual Atmos Health 3:183-194

Kuz'mina ZV, Treshkin SE (2009) Tendencies of change of the basic meteorological characteristics in Circum-Aral region. In: Ivanov AL, Kirushin VI (eds) Global climatic changes and prognosis of risks in agriculture. Russian Academy of Agrarian Sciences, Moscow, pp 467-476 (in Russian)

Létolle R, Aladin N, Filipov I, Boroffka NGO (2005) The future chemical evolution of the Aral Sea from 2000 to the years 2050. Mitig Adapt Strateg Glob Change 10:51-70

Micklin PP (1988) Desiccation of the Aral Sea: a water management disaster in the Soviet Union. Science 241:1170-1176

Micklin PP (1991) The water management crisis in Soviet Central Asia: the carl beck papers in Russian and East European, Stud. No. 905. Pittsburgh: Cent. Russ./East Eur. Stud

Micklin PP (2004) The Aral Sea crisis. In: Nihoul JCJ, Zavialov PO, Micklin PP (eds) Dying and dead seas: climatic versus anthropic causes. NATO science series IV: earth and environmental sciences, vol 36. Kluwer, Boston, pp 99-125

Micklin PP (2007) The Aral Sea disaster. Annu Rev Earth Planet Sci $35: 47-72$

Micklin PP (2010) The past, present, and future Aral sea. Lakes Reserv Res Manag 15:193-213

Muminov FA, Inogamova SA (1995) The climate changeable in Middle Asia. Tashkent, SANIGMI, Glavhydromet RUz, p 215 (in Russian)
O'Hara SL, Wiggs GF, Mamedov B, Davidson G, Hubbard RB (2000) Exposure to airborne dust contaminated with pesticide in the Aral Sea region. Lancet 355(9204):627-628

Opp C (2005) Desertification in Uzbekistan. Geogr Rundsch Int Ed $1(2): 12-20$

Opp C (2007) Vom Aralsee zur Aralkum: Ursachen. Wirkungen und Folgen des Aralsee-Syndroms (From the Aral Sea to the Aral Kum-causes and consequences of the Aral Sea syndrome). In: Glaser R, Kremb K (eds) Asien, Darmstadt, pp 90-100

Orlovsky L, Orlovsky N (2001) White sand storms in Central Asia. In: Youlin Y, Squired V, Qi L (eds) Global alarm: dust and sand storms from the World's Drylands, UNCCD report, Bangkok, pp 169-201

Orlovsky L, Tolkacheva G, Orlovsky N, Mamedov B (2004) Dust storms as a factor of atmospheric air pollution in the Aral Sea basin. Air Pollut 12:353-362

Palvaniyazov M (1989) The influence of dust storms on the habitats of certain mammals of the coastal zone of the Aral Sea. Probl. Osvoyeniya Pustyn. 1:55-59 (in Russian)

Popov VA (1998) The role of salt migration in the landscape genesis of the Priaral region. Probl Desert Dev 3-4:122-126

Prospero J, Ginoux P, Torres O, Nicholson S, Gill T (2002) Environmental characterization of global sources of atmospheric soil dust identified with the Nimbus 7 total ozone mapping spectrometer (TOMS) absorbing aerosol product. Rev Geophys 40(1): $1-31$

Ptichnikov A (ed) (2002) Sustainable development of ecology, land and water use through implementation of a GIS and remote sensing centre in Karakalpakstan. Bull. 3, NATO Sci. Peace Proj. 974101. Uzbekistan: Moscow (in Russian/English)

Rachkovskaya EI (2003) Botanical—geographic types of deserts. In: Rachkovskaya EI, Volkov EA, Khramtsov VN (eds) Botanical geography of Kazakhstan and Middle Asia (Desert region), pp 26-28

Razakov RM, Kosnazarov KA (1996) Dust and salt transfer from the exposed bed of the Aral Sea and measures to decrease its environmental impact. Aral Sea Basin 12:95-102

Saiko T, Zonn IS (2000) Irrigation expansion and dynamics of desertification in the Circum-Aral region of Central Asia. Appl Geogr 20:349-367

Semenov OE (1988) Model. Hydrometeorol Ecol 3:15-35 (in Russian)

Semenov OE (2009) Physicostatistical modeling of carrying sandysalt aerosol during storms in the Aral Sea region. In: Marburg international dust and sand storm (DSS) symposium "DSS and desertification", Marburg, pp 30-32

Semenov OE (2011) Introduction to experimental meteorology and climatology of the sand storms. Almaty, $580 \mathrm{pp}$ (in Russian)

Semenov OE (2012) Dust storms and sandstorms and aerosol longdistance transport. In: Breckle SW, Wucherer W, Dimeyeva LA, Oga NO (eds) Aralkum-a man made desert, the desiccated floor of the Aral Sea (Central Asia). Springer, Berlin, pp 73-82

Shardakova LY, Usmanova LV (2006) Analysis of dust storms in the Aral Sea region. Probl Desert Dev 3:30-34 (in Russian)

Shi GY, Zhao SX (2003) Several scientific issues of studies on the dust storms. Chin J Atmos Sci 27(4):591-603

Tursunov AA (1989) The Aral Sea and the ecological situation in Central Asia and Kazakhstan. Gidrotekh Stroit 6:15-22 (in Russian)

Usmanov VO (1998) Estimation of the influence of dusty salt transfer on the productivity of agricultural crops in the Priaral region. Probl Desert Dev 3-4:147-151 
Uteshev AS, Semenov OE (1967) Climate and Wind erosion of the soil. Kainar, Almaty (in Russian)

Whish-Wilson P (2002) The Aral Sea environmental health crisis. J Rural Remote Environ Health 1:29-34

Wiggs GFS, O'Hara S, Wegerdt J, Van Der Meer J, Small I, Hubbard R (2003) The dynamics and characteristics of aeolian dust in dryland Central Asia: possible impacts on human exposure and respiratory health in the Aral Sea basin. Geogr J 169:142-157

Yang Y, Squires V, Qi L (eds) (2002) Global alarm: dust and sandstorms from the world's drylands. UN Asia Regional Coordinating Unit, Bangkok 